\title{
A TRANSGRESSĀO DO TEXTO (Macunaima: linguagem dialógica)
}

Mario Chamie

Tese exposta no Curso de Extensão "Propósitos e Propostas de 22 ", realizado em Curitiba pelo Instituto de Letras e Artes, da Univer sidade Federal do Paranā, de 28 de agosto a 1 de setembro/72.

1. INTRÓITO

Com a crise dos gêneros literärios, com a implantação de uma poética que engloba e supera a dicotomia prosa e poesia ${ }^{1}$, torna-se dificil, em qualquer abordagem do problema da ficção, ignorar a necessidade de se criar novos padröes de anālise literāria. Uma anālise que terä por seu objeto muito menos um texto, visto em sua materialidade acabada de produto, do que um processo de produção textual, considerada em sua dinâmica interna de escrita permanentemente atualizável. Através de semelhante critério, o vasto repertório de textos que integram a literatura (ou uma determinada literatura) se abre a um tipo de enfoque em que é possivel interpretā-los não mais segundo modelos retóricos e cronológicos (como época, estilo, es cola, etc.), e sim segundo distinçōes de sistemas sincrônicos e globais de escrita.

Uma distinção fecunda e abrangente é aquela que separa o texto dialógico do texto monológico. 
Essa distinção - ainda que versando originariamente sobre a prosa defição no romance ${ }^{2}$ - se presta, pelas suas ricas im plicaçoses conceituais, ao encaminhamento de um postulado crítico que revela a ambiguidade intrínseca do próprio ato de escrever. Ambiguidade pela qual esse ato pode ser aberto ou fechado, convencional ou de ruptura, de negacão ou de afirmaça.

Julia Kristeva tentou o encaminhamento. Embora os resultados a que chega nem sempre sejam aceitáveis, a sua tentativa alarga a dicotomia de Bakhtine e oferece um quadro de referências críticas urilizável no universo geral de referências aplicado no estudo de "Macunaima" ${ }^{3}$, tomado aqui como um particular exemplo dialógico. Julia Kristeva, em värias oportunidades ${ }^{4}$, enfrentou oproblema. Onde, porém, fixou um jogo de contra posições esclarecedoras foi em "Le mot, le dialogue et le roman" 5 . Nesse ensaio, a semióloga sugere que três princípios, de um lado, regem o texto monológico, e que três outros, de outro lado, o texto dialógico.

os princípios do discurso monológico säo estes:
a) identidade
b) causalidade
c) oposiçāo por exclusão

os principios do discurso dialógico säo estes:

a) analogia

b) descontinuidade

c) oposigão näo-exclusiva

2.1 - Num plano de dedução, diríamos que, no discurso monológi- 
co, a identidade é oprincípio pelo qual um ou värios componentes de um texto articulado se determina em una individualidade dota da de uma coerência ünica de função e ação. Isso sem qualquer prejuizo de qualquer ambiguidade específica do compenente. Exem plo: a caracterização dos personagens no romance tradicional ${ }^{6}$. Nesse sentido, o personagem Bentinho, de "D.Casmurro", de Machado de Assis, apesar de todos os seus conflitos internos, a ge e reage, no contexto do 1 ivro, segundo uma lógica das emoções que o identifica e o individualiza. No livro, Bentinho é sempre o mesmo; ele não é o mesmo e o outro a um só tempo.

o principio da causalidade, por sua vez, é aquele pelo qual, no discurso monolögico, tudo sucede numa relação consequente e necessāria de efeito. A construção da frase e a organi zaçāo sintagmática dos eventos, na narrativa tradicional, serven de ilustração. A frase, aí, $\bar{e}$ construida sob origor linear de um sujeito que busca o seu predicado e de um predicado que busca os seus complementos. Vejamos estas duas frases iniciais de "D. Casmurro":

- Uma noite destas, vindo da cidade para o Engenho Novo, en contrei no trem da Central um rapaz aqui do bairro, que eu conhepo de vista e de chapéu.

- Cumprimentou-me, sentou-se ao pé de mim, falou da lua e dos ministros e acabou recitando-me versos.

Na primeira frase, o sujeito é o "eu" oculto do narrador que, através do seu predicado, encontra o seu complemento e objeto direto que é "rapaz". Na segunda, o "rapaz", complemento encontrado, passa a ser o sujeito de uma sērie causal de verbos cujo complemento $\vec{e}$ o narrador, agora transformado em objeto indireto. A série é esta: 
cumprimentou - sentou - falou -

acabou recitando.

Simultaneamente à construção da frase, a organização sintag mática dos eventos obedece à mesma lógica. Em "D. Casmurro", os fatores desta organização são claros. Basicamente, são eles:

Bentinho, Capitu e Escobar. As situaçōes se desenvolvem formando o seguinte sintagma central do entrecho:

1. Bentinho - Capitu

2. Escobar - Bentinho

3. Capitu - Escobar

4. Bentinho - Bentinho

Näo é difícil perceber que o entrecho é a solidāo de Bentinho, agravada pela presença de um filho (fruto possível da re lação (apitu-Escobar) e pela amarga memória reconstituinte dos eventos.

o princípio da oposigão por exclusão, no discurso monológico, é quase uma decorrência natural dos dois anteriores de iden tidade e causalidade. Pois, se Bentinho é idêntico a si mesmo e tem um carāter determinado que lhe dita ações e reações, ele ex clui um outro Bentinho, virtual e possivel, na sua configuração de personagem. Ele se opōe à negação de si mesmo enquanto tal. 2.2 - Já, no discurso dialógico, os princípios são outros. Em termos gerais representam o inverso e a negação dos três do dis curso monológico. Em termos particulares, porém, cada um além de negar os seus oponentes, é a afirmação de si mesmo e de sua total alteridade.

Assim, o princípio da analogia é aquele pelo qual os componentes de um texto articulado estão sempre em vias de se consti 
tuir, mas nunca constituídos em definitivo. Um personagem, aqui, é a identidade do que ele pode ser e não daquilo que é sem poder deixar de ser. A analogia gera a faculdade de ser semethante e diferente e tem na diferença a igualdade de sua funfäo. O exemplo mais ostensivo e brilhante, talvez, seja oferecí do por James Joyce, em "Finnegans Wake", com seus personagens Shem e Shaun. Shem, em dado momento, é "Same" (o Mesmo) e Shaun, "other" (o outro). No fluir confluente do texto, e sendo ambos extensöes parabölicas de Hörus e Thot (os deuses egípcios da escrita), fundem-se num "Th'other" absoluto. Vale dizer: são o que são, o que não são e as duas coisas juntas.

o princípio da descontinuidade é aquele pelo qual toda consequência é substituida pela correspondência provável e imprevi sível dos elementos ou unidades do discurso. Tanto a construção das frases quanto a distribuição dos eventos se dão, aqui, como dispositivos de linguagem que valem isolados ou em conexão com outrós de idêntica autonomia e validade. Oswald de Andrade, em "Memöria Sentimentais de João Miramar" e "Serafim Ponte Gran de", ou Jülio Cortazar, em "Rayuela", oferecem mostras cabais. Duas frases do oswald näo tem normalmente o menor liame lógico, a não ser o do vācuo da justaposição que lhes confere um sentido, aliās substituivel por outras justaposiçōes que com elas, isoladas ou em conjunto, se traçam. Exemplifiquemos três frases, de "Memorias Sentimentais de João Miramar", colhidas ao acaso. Estas duas do titulo "45. Aix":

- o lago gilete monoculava para o sol entre litografias con vexas.

- Montanhas espetavam têtas para a sêde azul do céu. 
Esta outra do titulo "49. Pas de Calais":

- Pequeno vapor que nos empurrou de Dover sobre rodas continuas no meio da noite.

Intercalando esta no vácuo da justaposição daquelas temos:

- o lago gilete monoculava para o sol entre litografias con vexas.

- Pequeno vapor que nos empurrou de Dover sobre rodas continuas no meio da noite.

- Montanhas espetavam tétas para a séde azul do céu.

Vê-se que a intercalação altera o sentido isolado das duas do título "45. Aix", mantendo, todavia, a pertinência da narrativa geral do livro. Isso graças à descontinuidade permutacional das enunciaçöes do texto oswaldiano.

Nesse mesmo sentido, Cortazar, em "Rayuela" ${ }^{7}$, chega a es tabelecer uma tabela de alternativas, em que a descontinuidade é um fator de formação de conjuntos sincrōnicos, e jamais linea res, de entrechos e de significação.

Por fim, o princípio da oposição näo-exclusiva é o resultado natural da descontinuidade e da analogia. Em ambos esses casos o que se verifica é a afirmaçāo do contraditório. Ou seja, é a negação da negação pela afirmação dos opostos que não se ex cluem, mas se integram. Em outras palavras: se um personagem, a qui, é o que é, ele não exclui a probabilidade de vir a ser outra coisa. Ou ainda: se um evento se conecta com outro, ele não exclui a probabilidade pertinente de vir a se conectar com tantos mais que o contexto de seu texto permita. Joyce, oswald e Cortazar seriam mais uma vez modelos de uma oposição näo-exclusiva. 
2.3 - Do ligeiro confronto entre os dois conjuntos de principios surgem algumas complementações inevitáveis.

No que se refere ao discurso monológico, as de que ele é: a) um sistema de manutençāo de significantes, com adaptações ocorrenciais de significados; b) uma linguagem, predominantemen te, denotativa.

No que diz respeito ao discurso dialógico, as de que ele é: a) um espaço de transformacão conjunta de significantes e de significados; b) uma linguagem, predominantemente, conotativa.

Nessas complementações, acentua-se a distância que vai de um discurso ao outro. Uma distância que pode melhor ser percorrida, com o auxilio de algumas noçöes operacionais que a tornem sensível e compreensível. No caso, as noções de significante e de significado ${ }^{8}$ que Greimas estipula, com razoável e ūtil senso didático, vem a propōsito. Significante, para ele, são "elementos ou grupos de elementos que tornam possivel o surgimento da significação ao nível da percepção"; e significado é a "significaça recoberta pelo significante e manifesta graças a sua existência" 9 .

Se, com efeito, considerarmos que o significante, no dis'curso monológico, se esgota na fixidez e na lógica fechada da identidade, da causalidade e da oposição exclusiva, notaremos que ele se mantém, assumindo o estado de um código estatuido que perdura no tempo como norma e sistema. Muitos seriam esses códigos ${ }^{10}$. A métrica, e suas formas fixas, o comprova. Basta constatar que os significados de um soneto ärcade, de um soneto romantico e de outro parnasiano não são suficientes para modificar o código da forma fixa, e perceberemos que tal forma 
se mantém independente

três tipos de significados naqueles três tipos de expressão poé tica. Constatariamos que, apesar das suas diferenças intencionais, a significação de cada soneto tem sua existencia manifesta condicionada por um só significante. Digamos: os três sonetos são apenas três ocorrências adaptadas de um só $e$ mesmo estatuto. Isto significa que um autor, ao escrever sob as normas desse estatuto, não só adotarä os padröes estáticos da lingua como ainda transformará a sua escrita num fenomeno denotativo desses padrões. o autor será, então, mais um intermediàrio exclusivo e obediente da projeção dominadora de um cádigo prédeterminado do que um seu interlocutor e produtor de textos.

Se, por outro lado, considerarmos que, no discurso dialógico, o significante e o significado surgem e se manifestam sempre conjunta e simultaneamente, verificaremos que ambos, a um só tempo, se constituem em cödigos cuja única norma fixa é a violação da fixidez das normas. Isto sifnifica que esses códigos se abrem à fluidez geracional da fala que, através da analogia, da descontinuidade e da oposiçāo năo-exclusiva, é a fonte e o espaço da ambivalência e da produçāo conotativa de sentidos. E como se, nesse texto, houvesse, alëm daquilo que Mallarmé chamou de a eliminaçāo da "presença elocutōria do sujeito" (autor), o estabelecimento de insubstituíveis e recíprocos niveis de interlocução entre texto, autor e leitor.

\section{NIVEIS DE INTERLOCUÇĀO}

A distinçāo entre texto monológico e texto dialógico encaminha, entre outras implicaçōes e a títulooperacional, o pro- 
blema geral da escrita enquanto norma e enquanto transgressão.

De fato, enquanto norma, ela reüne todas as condições do texto linear, coerente consigo mesmo e com o cōdigo estatuido que lhe pré-existe. Esse texto linear nāo se questiona, não se discute, seja antes, durante ou depois do feito. A rigor, ele é o império do signo e das gramāticas unificadas dos estilos lite rários.

Jā enquanto transgressão, a escrita preenche todas as condi çöes do texto que produz o seu prōprio processo, não só contradizendo códigos anteriores estatuídos como ainda tornando a ambiguidade, a ambivalência e a contradiçāo em fundamento das codificações possíveis da sua linguagem. Por isso, esse terto não estratifica nem imobiliza um universo unificado de sentido dita do por nenhum império ideológico do signo. Ao conträrio, cria nos Iimites do seu corpus as possibilidades de sentidos mültiplos e diversificados.

Desse modo, a ambivalência é a característica do processo produtivo da escrita dialógica, redutível a esta série de proce dimentos:

a) a escrita dialōgica se afirma negando cōdigos estatuídos anteriores, e se nega afirmando as suas próprias contradiçöes internas;

b) dentro desse jogo duplo e duplice, o autor perde a sua posição de preponderāncia absoluta e passa a ser um interlocutor entre os demais que, necessariamente, integram os níveis de produção da escrita dialógica;

c) esses níveis, nos termos da ambivaléncia que vai de uma negação da afirmação a uma afirmação da negação, podem ser reduzidos a três, a saber: 
1. o do autor em diälogo com o texto

2. o do texto em diálogo com o leitor

3. o do contexto em diálogo com o texto ${ }^{11}$.

Conceitualmente, portanto, a diferença entre o texto dialógico e texto monológico parece clara. Dum ponto de vista prático, porém, ela poderá ter sua maior objetivação.

\section{OBJETIVAÇĀO}

Acreditamos que uma fórmula didātica objetivará a diferença entre os dois tipos de escrita. Para a articulação da fórmula cujos fatores permitam especificar distinções, nos serviremos dos números 0 (zero), 1 (um) e 2(dois). Dada a linearidade e a ambivaléncia de um e outro texto e as possibilidades de sua manutenção ou transgressão, teríamos:

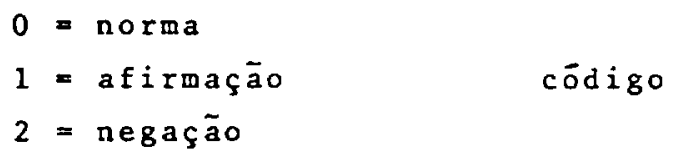

A intercorrência dos três componentes obedeceria a estas hi póteses de realização e movimento:

a) a da escrita que vai de o(zero) a I(um)apenas;

b) a da escrita que vai de I(um)a o(zero) para chegar a 2 (dois);

c) a da escrita que vai de 2(dois)a o(zero) para chegar c. 1 (um).

A hipótese a) diz respeito ao texto monológico de vez que ela consigna a afirmação da norma ( código estatuído). "D. Cas murro", de Machado de Assis, bem como, de modo geral, a prosa brasileira de antes de 1922 (romance naturalista e realista) se riam exemplo desse texto.

As hipóteses b) e c) dizem respeito ao texto dialógico já 68 
que consignam duas formas de transgressão da norma estatuída. Uma que a afirma para nega-1a e outra que a nega para afirma1a. Em relação a esta, o exemplo mais ostensivo da literatura brasileira, do moderaismo de primeira hora, é "Serafim ponte Grande", de oswald de Andradel2. Em relação àquela, melhor modelo que "Macunaima", de Mario de Andrade, não se encontra en tre nös.

\section{O EXEMPLO DE "MACUNAIMA"}

No quadro dessas considerações, a transgressão que a lingua gem de "Macunaima" representa atinge, mais do que simples nor mas de composição, todo um modelo de gēnero literārio.

A propósito, constataríamos o alcance da força transgressora do livro de Märio de Andrade, respondendo a três perguntas: a) qual o modelo de "Macunaima"?; b) em que consiste a Iinguagem de sua narrativa?; c) confrontada esta narrativa com o seu modelo, quais os aspectos demonstrativos da transgressäo daí decorrente?

Em resposta à primeira pergunta, ocorre dizer de imediato que, pela sua visível filiação histórica, o modelo de "Macunaima" é o da "fābula de magia". Ocorre, tamberm, assinalar

que dois autores levantaram e sistematizaram as grandezas normativas com as quais a fábula de magia configura a sua modelaridade. São eles: Vladimir Ja. Propp e A. J. Greimas.

propp, como é sabido, levanta a estrutura do conto popular russo, a partir de um inventário de suas funçöes e das esferas de ação a que essas funções correspondem"13. Em seu 1ivro "Mor fologia da Fäbula", Propp relaciona 31 (trinta e uma) funçōes 
para 7 (sete) esferas de ação.

As trinta e uma funçōes são estas:

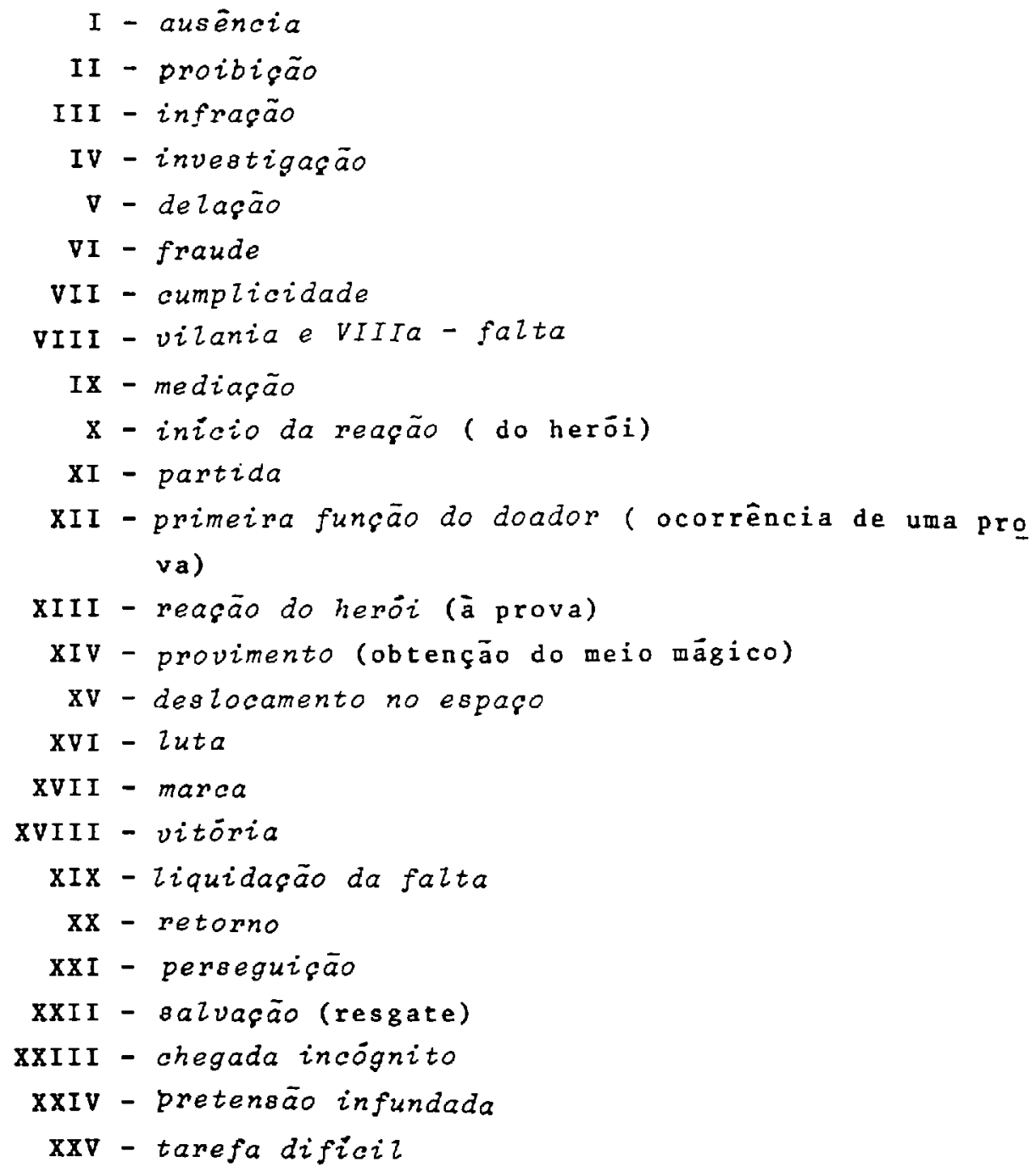




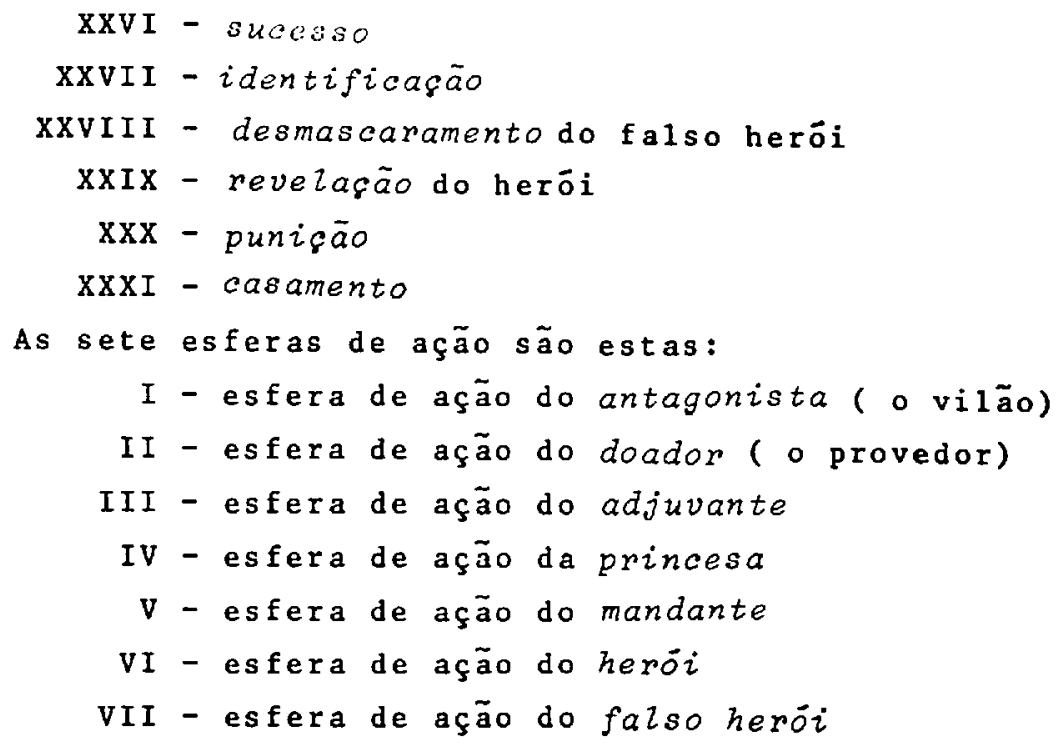

Se considerarmos todas as funçōes como atos dos personagens ("atores") e as esferas como "actantes", teremos o seguinte:
a) todas as trinta e uma funçöes ocorrem nos limites das sete esferas;
b) cada esfera representa um personagem;
c) cada personagem incorpora ou $\bar{e}$ sujeito de uma ou mais de uma ação.

Resulta daí que a "fäbula de magia" é uma narrativa de sete personagens, com uma ordem sucessiva obrigatória de trinta e uma funçōes. Estas são as variāveis das esferas que são invariantes.

A.J. Greimas, por sua vez, procedeu a uma revisão das colocações de Propp, reduzindo o inventārio de funçōes e o número de esferas actanciais. Para a primeira redução, argumenta Grei- 
mas: "Essas trinta e uma funçōes constituem um inventārio muito longo para que sua estruturação possa ser vislumbrada. E preciso, então, tentar reduzí-lo, seguindo, inicialmente, a sugestão do próprio Propp, que entrevê a possibilidade de acoplar as funções. Mas o acoplamento, nesse estägio, não pode ser senão empírico e se baseia sobre uma dupla exigência: uma condensação da narrativa em unidades "episódicas", ficando claro que os episódios a prever devem ser dotados de caráter binário e constituidos de duas funções apenas"14.

Para a segunda redução, Greimas, também por processo de opo siçöes binārias, converte as sete esferas a um esquema composto pelo que ele denomina de "categorias actanciais". Essas categorias, centradas no eixo sujeito-objeto, se desdobram analogicamente em Destinador X Destinatärio, Adjuvante X Oponente. E o fundamento do binarismo cabe ser localizado no "desejo" que, em sua polivalência, move um termo das oposiçóes ao outro. De fato, nas fábulas e nos contos populares, o que motiva a atração do herói para a heroína senão o "desejo" de prêmio e posse, ou a atração do herói ao vilão señao o "desejo" de reparação e de restabelecimento do bem?

E verdade que Greimas vai além dessas simples reduçōes 15 . Mas, de qualquer modo, não altera o código ou as normas do estatuto que define a fábula de magia. Ao contrário, ele corrige Propp para melhor ratificar as normas.

Em resposta à segunda pergunta, diremos que "Macunaima" é uma fäbula de fābulas ou um "discurso de discursos". A sua organização compositiva o demonstra. Mário de Andrade coletou len das, contos populares, romances, etc. do vasto repertório bra- 
sileiro. Respeitou a integridade prosódica de cada um deles. Na sucessão dos dezessete capítulos de "Macunaima", distribuiu to. dos os romances, contos e lendas, mantendo as suas diçóes, episódios. Só não manteve os personagens nucleares, o! quais foram substituidos por um único, Macunaima, que, ao incol porar os demais, perdeu o seu próprio caráter. Por ter todos o! caractéres, ficou um herōi sem nenhum. Mário deu a essa monta. gem e grande justaposição metonímica o nome de rapsódia. Ou se. ja: o nome que define o cruzamento de textos heterogêneos, cu. ja relação integrada de interdependência e complementaridade produz um intertexto homeogêneo.

Fruto, portanto, de uma disparidade unificada, a linguager de "Macunaima" não deixa de se fazer e de se cumprir num apare! te grande sintagma linear que, enquanto entrecho da narrativa se enquadra e comprova, perfeitamente, os padrões do gênero $1 i$. terário a que pertence.

o entrecho é claro e explícito e podemos seguí-1o especifi. cando a trajetória do heröi, a presença dos personagens e a cr! nologia das ações no desenrolar dos capítulos.

Em sintese, a trajetória do herōi se compilaria em: a) nas. cimento às margens do Uraricoera; b) infância às margens do Ur: ricoera; c) migração a partir do Uraricoera; d) conquista d muiraquitã no percurso; e) perda da muiriquitã no percurso; f transferência para são Paulo, em busca da muiráquita, g) reco! quista da muiraquitã; h) retorno ao Uraricoera, com a muiraqui tã reconquistada.

A presença dos personagens se configuraria assim: a) mãe dois irmãos (Jiguê e Maanape), Sofará ( companheira de Jiguê) 
- herói às margens do Uraricoera; b) dois irmãos, Iriqui (nova companheira de Jiguê), Ci, ofilho de Macunaima, o herói na migração; c) os irmãos, Suzi (outra nova companheira de Jiguê), Wenceslau Pietro Pietra, o herói, en Sāo Paulo, na busca e conquista da muiraquitã; d)os irmãos, a Princesa ( última companheira). opapagaio, a Uiara, o herói, no retorno ao Uraricoe $\mathrm{ra}^{16}$.

A morfologia das ações se catalogaria em: a) estägio às mar gens do Uraricoera,com peripécias de caracterização de comportä mento (capítulos I e II); b) partida das wargens do Uraricoera, com primeiras provas e provações (capítulos III e IV); c) prepa raçāo, com peripécias, para transferências a são paulo (capitu10 V); d) chegada, com peripēcias, a são Paulo, em busca da muiraquitã (capítulo V); e) permanência em são paulo, com açöes e protelaçóas, na luta de reconquista da muiraquita ( capítulos VII e XII); f) fim da permanência em São Paulo, com açóes e obtenção da vitória na luta pela reconquista da muiraquita ( capí tulo XIV); g) a volta, como herói incógnito, ao Uraricoera e pe ripécias com o objetivo de reparação da carência e pobreza da região (capítulos XV e XVI); h) a fixação e a morte, depois do retorno (capitulo XVII e "Epilogo").

Sobre estes três suportes isomörficos do entrecho, Mário de Andrade constrói sua linguagem, fundamentada no uso coloquial da fala, na diç̧ão do dito popular e num permanente recur so imaginärio de negação ou anulação do espaço e do tempo da narrativa 17 .

Em resposta, pois, à terceira pergunta, diríamos que a linguagem, de "Macunaima" é, num primeiro plano, de constatação, e 
afirmação das normas do seu modelo. Todavia, ressaltada sua con dição de "discurso de discursos", e transpondonos para o plano do confronto entre os seus três suportes isomórficos e as grandezas constantes definitōrias do gênero "fäbula de magia", veri ficaremos que o intertexto de Mário de Andrade, ao contrário de "Serafim Ponte Grande", de Oswald, afirma para negar e näo nega para afirmar.

Façamos o confronto.

Em relação às 31 funçōes de Propp (reduzidas a 20 por Grei mas), temos que toda escala é preenchida por "Macunaima", numa redução ainda maior. De fato, as 31 ou 20 funçöes, estão contidas em 9 (nove) perfeitamente assinaläveis na nossa fabulosa rapsódia. São estas:

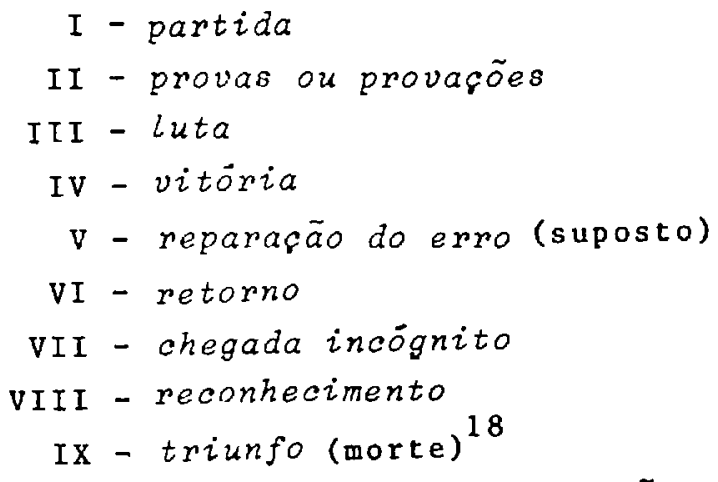

Em relação às sete esferas de ação, o enquadramento é, formalmente, perfeito. São estes os personagens de "Macunaima" que preenchem a tábua actancial de Propp:

I - esfera do vilão: Piaimã

II - esfera do doador: Império do Mato

III - esfera do adjuvante: os manos, coisas e bichos 
IV - esfera da princesa (herōina beneficiäria): $C i, M a ̃ e$ do Mato

V - esfera do mandante: as icamiabas

VI - esfera do heröi: Macunaima

VII - esfera do falso herōi: piaima $\tilde{a}^{19}$

Com esse completo preenchimento das funções e das esferas de ação, a narrativa de Mário de Andrade adota e se enquadra no modelo da "fābula de magia". Mas esse enquadramento, dada a natureza dialógica da escrita que é uma "fäbula de fäbulas", cons tata o modelo não para afirmā-10 e sim para negá-1o. Isto significa que a Iinguagem de "Macunaima" tem sua forma especifica de transgressão e não se esgotarā nunca nos esquemas estruturais do gênero a que, consciente e parodisticamente, adere. Isto significa também que a narrativa da rapsódia de Mário de Andrade é o espaço confluente de um diảlogo que envolve, a qual quer nivel, tanto o leitor, quanto o autor e o texto. Pōe-se, as sim, como uma leitura-escritura, atravēs da qual, a partir do seu universo mesmo de açōes, os esquemas codificados do gēnero são violados e passam a ser meros referentes negativos da sua construção intelectual livre e aberta.

o confronto, portanco, que faremos, a título de resposta à terceira pergunta, näo daria margem a maiores dúvidas sobre a nítida transgressão macunaímica.

Confrontemos, apenas e para fins de simples ilustração, as esferas de ação de nümeros II (do doador), IV (da heróina be neficiāria) e VI ( do herói), que valen como actantes das funçöes I (partida), II (provas ou provaçöes), VI (retorno), VII (chegada incógnito), VIII (reconhecimento) e IX (triunfo) e 
registremos o indice transgressor de "Macunaima".

\section{Com efeito:}

1. esfera de afão II / funcöes I e II

Dentro das normas da "fábula de magia", o herói

parte

(ausenta-se) porque assume a missão, decorrente de contrato com o doador, de ir ao encalço do violador de uma proibição para reparar a ordem violada.

No caso de Macunaima, porém, o contrato é um caso lúdico e a missão, um vêzo circunstancial e parodístico.

Macunaima, ao partir (ausentar-se) das margens do Uraricoera, com os manos, só por fato fortuito encontra Ci, Mäe do Mato. Domina-a, com ajuda de Jiguê e Maanape. Do resultado de sua posse violenta, nasce-lhe o filho que, mais tarde, morre. Ci, também, morre e doa-lhe o meio mä gico que é a muiraquitä. Essa doação, nos termos da lenda, $\bar{e}$, a rigor, uma prenda do Império do Mato. Ao perdê 1a, Macunaima deseja reave-la não tanto para vir a ser - Imperador da Icamiabas (amazonas do Império) quanto restabelecer o $1 \mathrm{i}$ ame nostälgico e sentimental com $\mathrm{C} i$ que, a exemplo de quase todos os personagens do livro, se transforma em estrela ou constelação, numa evidente simbologia do desencanto e do senso de inutilidade que, em todo o entrecho, inspira a rapsodo e as criaturas de sua fábula. Desse modo, as provações que o herói teria que enfrentar, nessa espécie de peregrinação e demanda do seu "graal" folclörico, são mais eventos lendārios e pitorescos, que ressaltam a sua fantastica incolumidade onírica, do que obstäculos reais no plano da "realidade" 
ficcional de sua ação. As provaçōes, por exemplo, sofridas a caminho de São Paulo, onde se encontra a muiraqui$t \tilde{a}$, são intercalações e enxertos de contos populares cir cunscritos a $5 i$ mesmos como textos e fragmentos episódicos dentro do intertexto rapsödico global. o episódio da "perseguição" de Capei, no capitulo IV (Boiuna Luna), é uma, entre outras amostras disso.

2. esfera de ação IV/ funcōes IV, VI, VII e VIII

Dentro das normas da "fábula de magia", a princesa (conforme a nomenclatura de Propp) cobre, na qualidade de he roína beneficiária, funções que envolvem desde o "desmas caramento" do falso herói até a identificaçäo do verdadeiro heroi que retorna e com quem contrai "nüpcias". ora, todas essas funçōes, na sucessão sintagmātica da narrativa macunaímica, são compendiadas pelo avesso, a ponto de ficarem a um passo da impossibilidade. Se não, vejamos. Depois de reconquistada, vitoriosamente (funçäo IV), a muiraquitã, Macunaima retorna (funçāo VI), chega incögnito (função VII), mas não pode ser reconhecido(fun ção VIII), porque não só $C i$ (a heroína beneficiäria) jā era morta, quando da partida do herói, como o Império do Mato jā não passa de uma ilusāo desolada. 0 deslocamento, portanto, de Macunaima, num espaco e num tempo de fābula que Mārio de Andrade prima por anular e transgredir, cai no vazio. E um vazio tornado mais agudo pelc arremedo e pela paródia que o nosso rapsodo faz da função do reconhecimento. Paródia e arremedo estäo nesse episódio lapidar relativo à volta de Macunaima às mar- 
gens do seu Uraricoera: "O herōi ficou descansando. Estava assim quando sentiu no ombro um peso de mão. Virou a cara e olhou. Junto dele estava um velho de barba. 0 velho falou:

- Quem és tu, nobre estrangeiro?

- Não sou estranho näo, conhecido. Sou Macunaima o heröi

e vim parar de novo na terra dos meus. Você quem ē?

velho afastou os mosquitos com amargura e secundou:

- Sou João Rama1ho.

Então João Ramalho enfiou dois dedos na boca e assoviou. Apareceram a mulher dele e as quinze familias de escadinha. E lá partiram de mudança buscando pagos novos sem ninguér".

3. esfera de ação VI / funções VI, VII, VII e IX

Dentro das normas da "fābula de magia", o herói, cumprida a sua missão, retorna e uma vez reconhecido, não só ocorre o desmascaramento do falso herói, como ainda o triunfo lhe bafeja. O percurso de Macunaima sustenta esse entrecho, sendo a sua cabal negação. Isto porque Macunaima, ao invés de ser o sujeito vitorioso de un acres centamento das funçōes que desempenha, é o objeto derrotado de um esvaziamento delas. Veja-se, em síntese: ele reconquista a muiraquitã, mas contrai impaludismo; volta com seus permanentes adjuvantes, os manos também vitimados pela doença, e os elimina: incógnito e "estrangeiro" quer salvar seus feitos, mas só consegue ter a memōria de les, através da companhia soläria e repetitiva de um papagaio; quer sentir um ültimo renascimento de suas açóes 
triunfantes, mas $\bar{e}$ "comido" pela sua sedutora uiara,etc. Em conclusão: o seu triunfoé a sua morte e a certeza de sua impotência na terra, para ser a constelação da Ursa Maior $1 \bar{a}$ no céu.

6. CONCLUSÃo

Os três breves exemplos citados acima parecem ser suficientes para demonstrar a polivaléncia característica da rapsódia de Mário de Andrade. Polivaléncia que, de resto, se assenta num primeiro e fundamental diálogo, do qual rodos os outros derivam. Esse diālogo é o que se faz entre o autor e o(s) texto(s). Sem düvida, numa relaçāo dialógica, Mário de Andrade, reescrevendo, a partir de sua mūltipla leitura, grande número de fäbulas do imaginārio amazónico, escreveu a sua fábula, impondo sobre a univoca heterogeneidade de todos os contos populares apro veitados, a ambígua homogeneidade de sua escrita.

Mário de Andrade produziu, assim, uma fábula que afirma e nega ao mesmo tempo, e que, por isso, se abre a outros niveis de diālogo como o do leitor como texto e o do texto com o contexto. Isso, numa total e livre confluência em que tudo é anälogo, descontínuo e passível de uma fecunda alteridade. A confluência, enfim, de uma verdadeira escritura-leitura ou leitura -escritura que vai de $I$ (um) a 0 (zero) para chegar a 2 (dois).

NOTAS

(1) Ver "linguistique et Poétique", de Roman Jakobson, em "Essais de Linguistique Génērale", Les Editions de Minuit, Paris, 1963, päg. 209 e segs. 
(2) Ver "La Poétique de Dostoievski", de Mikhail Bakhtine, Aux Editions du Seuil, Paris, 1970. Bakhtine, com a concepção do romance polifōaico, supera o esquematismo dos formalistas russos e apresenta, a partir da anāilse da narrativa de Dostoievski, a importante e Eecunda dicotomia entre discurso monológico e discur. so dialögico. A tese de Bakhtine surgiu, em 1929, em russo, como titulo de "Problemas da obra de Dostoievski".

(3) E curioso que Märio de Andrade, nos seus primeiros do cumentos teóricos, concebesse o texto como uma escrita polifônica, a exemplo de Bakhtine. Em 1922, sete anos antes do autor russo, escrevia Märio de Andrade: "Denominei esse aspecto da literatura modernista: PoLIFONIA POETICA. Razões: simultaneidade é a coexistên cia de coisas e fatos num momento dado. Polifonia é a união artistica simultânea de duas ou mais melodias cujos ciaitos passageiros de embates de sons concorrem para um efeito total final. Foi esta circunstancia do EFEITO TOTAL FINAL que me levou a escolher o termo polifonia". Ver "A Escrava que não é Isaura", Livraria Martins Editōra, 1960, päg. 268. Nessa linha polifonica de efeito total final, foi escrita a "rapsōdia" que é o texto dialógico de "Macunaima", jā que esse livro, na linha da menipéia, é uma fábula de $f \bar{a}-$ bulas ou um "discurso de discursos".

(4) Ver "La productivité dite Texte", em "Communications", n.11; "Poésie et Negativité", em "L'Homme", 
de 8/2/1968; "Le Texte clos", en "Languages", n. 12, etc.

(5) Ver "Recherches pour une Sémanalyse", Aux Editions du Seuil, Paris, 1969 , päg. 143 e segs.

(6). Chamanos, aqui, de romance tradicional a narrativa na turalista e realista que, historicamente, representam um momento pleno de configuração do gênero literärio.

(7) Ver "Rayuela", Editorial Sudamericana, Buenos Ayres, 11a. edição, 1969. Cortazar abre o livro com um "Tablero de Direcciōn", cuja primeira Erase é esta: "A su manera este 1 ibro es muchos libros, pero sobretodo es dos libros". A seguir, Cortazar convida o leitor a eleger suas alternativas.

(8) A.J. Greimas redimensiona os conceitos de significante e de significado de F. de Sausure. Como se sabe, Saussure identifica o significado com o conceito e o significante com a imagem acústica de um signo.

Ver "Cours de Linguistique Générale", de F. de Saussure, Payot, Paris, 1966, päg. 99.

(9) Ver "Sémantique Structurale", de A. J. Greimas, Larousse, Paris, 1966 , päg. 10 .

(10) Tomamos, no caso, cōdigo como uma organização de prin cípios fechados que, necessariamente, são observados na elaboração de um texto. A retórica poética tradicional é um vasto repositōrio de tais princípios.

(11) Julia Kristeva entrevê esses três níveis em três dimensões bäsicas: "o sujeito da escrita, o destinatärio e os textos exteriores (três elementos do diālo- 
go)". Ver "Recherches pour une Sémanalyse", ed. cit., päg. 145 .

(12) Realmente, a escrita de "Serafim Ponte Grande" parte de 2 (dois) a 0 (zero) para chegar a 1(um). Isto é: parte da negação da norma estatuida para estatuir a transgressão como regra. Os indices de negação para a afirmação são claros e aferíveis em alguns níveis nítidos e definitivos, a saber: a) nivel de proposta de uma escita deliberadamente anárquica: - o livro, segundo o autor, "foi escrito de 1929 (era de Wall Street e Cristo) para tras" e pode "ser traduzido, re produzido e deformado em todas as línguas"; o autor, no livro, pretende ter feito" o epitáfio do. que fui", que é a sua forma de fazer o "necrológio da bu guesia"; o livro não quer ser um romance naturalista e faz a isso uma referência irōnica e contraditória, no início da parte "Folhinha Conjugal ou seja Serafim no Front"; b) em nível de um eu analógico do personagem: - de fato, Serafimsão três "eus", distribuidos num "eu-oswald", num "eu-Serafim" e num original "euêle", restando, para cada um, un tempo e um modo no plano da memória que preside o entrêcho do livro; os personagens também não têm coerência situacional (exemplo: Pinto calçudo é expulso do romance, mas volta num momento em que a narrativa é a crítica distanciada de si mesma); c) em nível de descontinuidade estru tural: - Oswald adota uma sucessão de frases autônomas e justapostas; utiliza notações diferenciadas de registro prosödico (usa verso, usa prosa, introduzo 
diálogo teatral, insere textos de leituras que se transformam em escritura do livro, etc.); Oswald ado ta uma cronologia töpica e desconexa de capítulos e mesmo de partes inteiras do livro. A prova, enfim, de que toda essa transgressão afirma a sua própria regra está em que qualquer que seja a interferência do leitor, a leitura unificada de Serafime ressalta da e ressaltävel.

(13) Ver "Morfologia della Fiaba", de Vladimir Ja. Propp, tradução italiana, Giulio Einaudi Editore, 1966, Torino. Consultar especificamente os capítulos terceiro ("Funções dos Personagens") e sexto ("Distribuição das funçöes segundo os personagens").

(14) As 20 funçóes levantadas por Greimas sāo estas: Iausēncia; II - proibição vs. violação; III - busca vs. submissão; IV - decepção vs. submissão; v - trai ção vs. falta; VI - ordem vs. decisão do heröi; VIIpartida; VIII - ocorrência da prova vs. confrontação com a prova IX - recepção do adjuvante; X - transferência espacial; XI - combate vs. vitória; XII - mar ca; XIII - liquidação da falta; XIV - retorno; XV perseguição vs. Iiberação; XVI - chegada incögnito; XVII - realização de uma tarefa vs. sucesso; XVIII reconhecimento; $X I X$ - revelaçäo do traidor vs. revelação do heröi; XX - puniçãovs. casamento. Complementa Greimas: "Vê-se que apenas certo número de fun çöes se prestam ao acoplamento. o novo inventário, a inda que mais reduzido, não é mais manipulāvel que o primeiro". (Op. cit., págs. 194/5). 
(15) Greimas parte para uma nova síntese e para novas conformações metodológicas, que implicam numa revisão e numa redimensão do levantamento de Propp. A análise dessa redimensão não cabe, agora, no āmbito específico deste estudo. Ver, em particular, os capítulos "Re flexöes sobre os modelos actanciais" e "Para a pesqui sa dos modelos de transformação", de seu "sēmantique Structurale".

(16) Desnecessārio acrescentar que hà uma soma de personagens complementares que avolumam as peripécias e ações do livro e que decorrem do pröprio repositōrio de contos populares e fábulas citados" em mosaico" por Mário de Andrade. Um interrelacionamento da presença de todos esses personagens poderā significar uma ampliação das matrizes e das constantes da narrativa rapsódica do autor de "Macunaima", coisa que temos feito em conferências e outros escritos.

(17) Alguns exemplos diretos da anulação do espaço e do tempo da narrativa fabulosa: o episódio da fuga de Ma cunaima, da cabeça de capei, num tempo e num espaço imaginārios, e oncontro com o Bacharel de Cananéia; - episódio da fuga que o herói empreende de Ceiuci em que, com a ajuda mágica do tuiuiū, se transforma em avião e reencontra Bartolomeu Lourenço de Gusmão. Fragmento do primeiro episódio: "Correndo correndo I gua e meia adiante deram com a casa onde morava o Bacharel de Cananéia. o coroca estava na porta sentado e Iia manuscritos profundos. 
Macunaima falou pra ele:

- Como vai, bacharel?

- Menos mal, ignoto viajor.

- Tomando a fresca, não?

- C'est vrai, como dizem os franceses".

Fragmento do segundo episódio: "Logo o tuiuiú se transformou na máquina aeroplano. Macunaima escanchou no aturiá vazio e ergueram vôo. Voaram sobre o chapadäo mineiro de Urucuia, fizeram o circuito de Itapecerica e bateram pro Nordeste. Passando pelas dunas de Mossoró, Macunaima olhou pra baixo e enxergou Bartolomeu Lourenço de Gusmäa, batina arregaçada pelejando pra caminhar no areäo. Gritou pra ele: Venha aqui com a gente, ilustre! / Porém o padre gri tou com um gesto imenso: - Basta!".

(18) Na mesma medida em que Greimas reduz as 31 funções de Propp a 20, sob o critério de uma fusão bināria, de vez que, por ex., a proibição implica em violação, a perseguição em liberação, etc., cabe, em relação a Macunaima, e a título de ilustração crítica, reduzir pelo mesmo processo a nomenclatura de Greimas. Assim, "prova" ou "provação" já contēm em si a necessidade da confrontaçäo de um obstáculo, como "partida" jā contēm em si a "ausência". Isto posto, a classificação de nove funções, que aventamos, tem o valor de uma täbua operacional, pertinente no quadro geral do texto de afirmação da afirmação para chegar à negação que é "Macunaima". 
(19) Esse elenco de personagens (da tábua de esferas de ação) traz em si uma aguda ambiguidade central porque a rapsōdia macunaimica tem na paródia um seus maiores fundamentos. A amostra inequívoca dessa paródia està na "Carta pras Icamiabas". O herōi a escreve, segundo três alvos parodísticos: a) o da imitação sarcástica de Pero Vaz de Caminha; b) o da reverência irônica e maliciosa ao seu "doador" que säo as amazonas do Impārio do Mato; c) e o do documento de um cumprimento de tarefa, assumida por contrato, buscando, por antecipação cômico-cínica, uma compensação oportunística. No primeiro alvo, está claro que S. Paulo é como a terra descoberta, e Macunaima faz a vez do "escriba de El Rey", usando, por derrisão na sua linguagem, um português ultra-re tórico a quinhentismo; no segundo alvo, tanto quanto Caminha deu conta da descoberta, o herói dá conta de suas impressōes da terra nova, onde MUITA SAUVA E POUCA SAUDE OS MALES DO BRASIL SÃO, relatando, ao mesmo tempo, os esforços para a conquista da muiraquitä; no terceiro alvo, por causa dos esforços e da certeza da reconquista, o herói pede alvíçaras, seguindo a tritha de Pero Vaz que pede favores a El Rey para um seu parente em Áfica. O fim da carta do herói é expressivo: "Hemos por bem repetir entretanto que as nossas relaçōes com o doutor Venceslau são as milhores possíveis, que as negociaçöes estão entaboladas e perfeitamente encaminhadas; e bem poderíeis enviar de antemão as alvígaras que enunciamos 
atrās. Com pouco o vosso abstémio Imperador se con tenta; si nāo puderdes enviar duzentas igaras cheias de bagos de cacau, mandai cem, ou mesmo cinquenta. Recebei a benção do vosso Imperador e mais saūde e fraternidade. Acatai com respeito e obediência estas mal traçadas linhas; e, principalmente, não vos esqueçais das alvíçaras e das polonesas, de que muito hemos mister. / $\mathrm{Ci}$ guarde a Vossas Excias". Por sua vez, o fim da carta de Pero Vaz de Caminha não deixa de lado o tom oportuno de pedido de compensação: "E pois que, Senhor, é certo que, assim, neste cargo que levo, como em outra qualquer coisa que de vosso serviçofôr, Vossa Alteza hä de ser de mim mui to bem servida, a Ela peço que, por me fazer singuIar mercê, mande vir da ilha de säo Tomé a Jorge de osório, meu genro - o que d'Ela receberei em muita mercê. Beijo as mãos de Vossa Alteza". 